\title{
IDENTIFICATION OF CONVICTS IN HUNGARIAN PRISONS
}

\author{
Katalin KONDÁS \\ Óbuda University, Budapest, Hungary \\ kondaskatalin@gmail.com
}

\begin{abstract}
Personal identification is a crucial element of some safety-technology systems. The same applies to facilities brimming with safety devices, in particular, in penalty institutions, prisons. My goal is to present a comprehensive picture of the identification method used in Hungarian prisons. There is no other summarizing document available on identification. My present paper is based on the 12 years of experience that I have gained in the Penalty Enforcement Organisation in the area of information technology since 2007. I have been analyzing and researching the personal identification of convicts based on their biometric characteristics. In 2004, a well-functioning, object-based identification method was established. This article will give an overall picture of the identification system(s) used in Hungarian prisons as well as of my former plans to renew the identification methods of convicts.
\end{abstract}

KEYWORDS: prison, biometrics, identification

\section{Introduction}

Biometric identification is one of the most wide-spread and most modern personal identification methods, whose goal is to establish an individual's identity with confidence, rapidity and credibility. Due to the explosive and dynamic progress of information technology, biometric identification methods are undergoing continuous and quick development. This type of identification can be diverse depending on the requirements, goals and the allocated budget and how the desired identification system can be implemented.

In Hungarian penalty enforcement, biometric identification is not yet widespread. I will outline the identification method of convicts used in the penalty organisation and its importance in prison residents' lives. In total, there are over 17.000 convicts in Hungarian prisons. The data management of this significant number of people requires an extensive database.

In the penal institution, the personal identification of inmates is particularly crucial in the following situations:

- admission,

- receiving visitors,

- starting work in prison,

- shopping in the prison shop,

- using the public phone attached to the corridor wall,

- the activities of right enforcement (Kondás \& Szücs, 2020).

It is my goal to describe the operation of the identification system used in Hungarian prisons. In this paper, I will mainly focus on the identification process during inmates' use of the public phone and the prison shop.

My research still concentrates on how identification methods and their effectiveness could be improved and 
implemented during the time of imprisonment and in the various systems operated in the different professional areas.

I genuinely believe that the physical implementation of a long-desired biometric identification system is already on our doorstep in the Hungarian Penalty Enforcement Organisation.

\section{Identification of Prisoners}

After a custodial sentence has been imposed, the Penalty Enforcement Organisation determines when and in which prison the convict will apply to complete their sentence. The convict's identity must be checked.

As soon as the prisoner arrives at the penal institution, their data are registered in the central database; all available information gets recorded in a computer programme specially developed for this purpose. The database contains the current and past data and the documents related to the sentence and the enforcement of measures (Hungarian Prison Service in Service of Justice, 2020). Personal identification is necessary during the admission process of inmates and in the course of their daily activities, e.g. phone use or shopping.

\subsection{Prison Register}

Upon the admission of a prisoner, they get photographed and receive a register number. These can be disclosed only with relevant permission. Information is stored in a database, where the personal records of any inmate can be searched at any time. The personnel of the various units (disciplinary, security, registration, healthcare, re-integration, prison employment) can view and have access only to the functions and data relevant to their use. Should further information be added to the personal records, the time of entering the new data and the name of the officer documenting them are also recorded and can be searched. The record database is severely monitored.
Ensuring the availability of information and the protection of data from the access of unauthorised individuals are permanent tasks within the framework of the operation of the IT system. For the basic traceability of the management and use of special data, the identification of users and the authentication process of information are of pivotal importance (Kondás, 2018).

Although the inmate record database is multi-layered, the database of the Penalty Enforcement Organisation is not identical to that of the organs of the criminal justice system.

\subsection{Register Number}

All prisoners receive an individual register number when they are taken into confinement or custody; upon admission to the penal institution. This register number is a code consisting of two letters and four numbers, which remain with the convicts during their entire imprisonment period, even if they are transferred to another penal institution. Should they be sentenced to confinement again for an already known crime, the individual's register number will regularly stay the same. In other words, they will be registered under the same code.

\subsection{Barcode Cards}

Upon admission to prison, personal items and money are deposited, so inmates have no ID cards or money with them. These items are safeguarded by the penal institution and will be returned to their owners upon release. As convicts are not to own cash, but shopping in the prison shop or using the prison phone works only with money, they can make use of these services with the help of a virtual account. To resolve this issue, a method using a card has been devised. All inmates receive this card upon entering confinement, which also serves as a means of identification. With the help of this so-called barcode card, the available amount can be established from the data records of the prison. 
The front of the card contains the following data:

prisoner's name,

prisoner's register number,

prisoner's photo,

individual barcode.

\section{Identification of Prisoners in Hungarian Prisons}

\subsection{Phone System with Barcode Card}

A prison phone system has been operated in all penal institutions of this country since 2004. The basic concept of the system is that all convicts are given a barcode ID card, which is registered in the central prison database alongside a biometric identifier of the inmate. In practice, the database also includes a photograph of the convict. When the given individual wishes to make a phone call, the phone device attached to the wall will detect the barcode card, then the camera installed in the phone takes a photo of the user and compares it to that featured in the database. If they prove to show the same person, the inmate can start dialling.

\subsection{The Purpose of and the Use of Barcode Cards in the Phone System}

The fundamental purpose of the prison phone system is to enable the prison personnel to check and listen into the phone calls of inmates. Another goal is to make all conversation should be controlled, all their features should be recorded and that the telecommunication fee should be automatically paid through the payment system.

It is cardinal that the prison's IT system can provide data in an event-driven manner to independent sub-systems, among others, the phone system and can communicate online with the shop's money register. All in all, the barcode card can be used for making phone calls and for shopping, provided the convict has the necessary funds. The use of this card is similar to that of bank cards in civilian life. After comparing the appropriate sums, the card codes must be updated, which means that the barcode will be allocated to each convict based on their register number (Kondás, 2013).

\subsection{Making Phone Calls}

The primary and most crucial step for making phone calls in the phone system is to identify the given inmate quickly and confidently. Upon initiating a phone call, the convict picks up the phone and receives an oral instruction to display their barcode on their card to the barcode reader and to face the camera. Following this step, the fading of the flash of the barcode reader demonstrates that the identification has been automatically performed. Should the camera's just-taken photo not agree with the one stored in the database, the phone indicates a defect and does not permit the call.

Then, the system immediately finds the relevant, necessary and accessible (for the given institution) data belonging to the barcode card in the database and displays those on the screen in an appropriate order. These data will be hereinafter be referred to as the regulation system belonging to a given inmate. Within this regulation system, a module of the phone system will retrieve the list of phone numbers the convict is allowed to call based on their permitted contact list from the institution's prison registry.

The identification of the inmate is possible, therefore, through the comparison of the photo retrieved from the prisoners' database and that made by the webcam placed next to the phone displayed on the officer's screen. This is the process of biometric identification. The webcam image shot at the time of visual identification and displayed on the screen - alongside the other parameters of the phone call - get stored and can be retrieved later. With this method, makers of unpermitted phone calls can also be confidently identified, and further control processes are facilitated.

Figure no. 1 shows the phone cabinet with the telephone receiver, the camera and the barcode reader. 


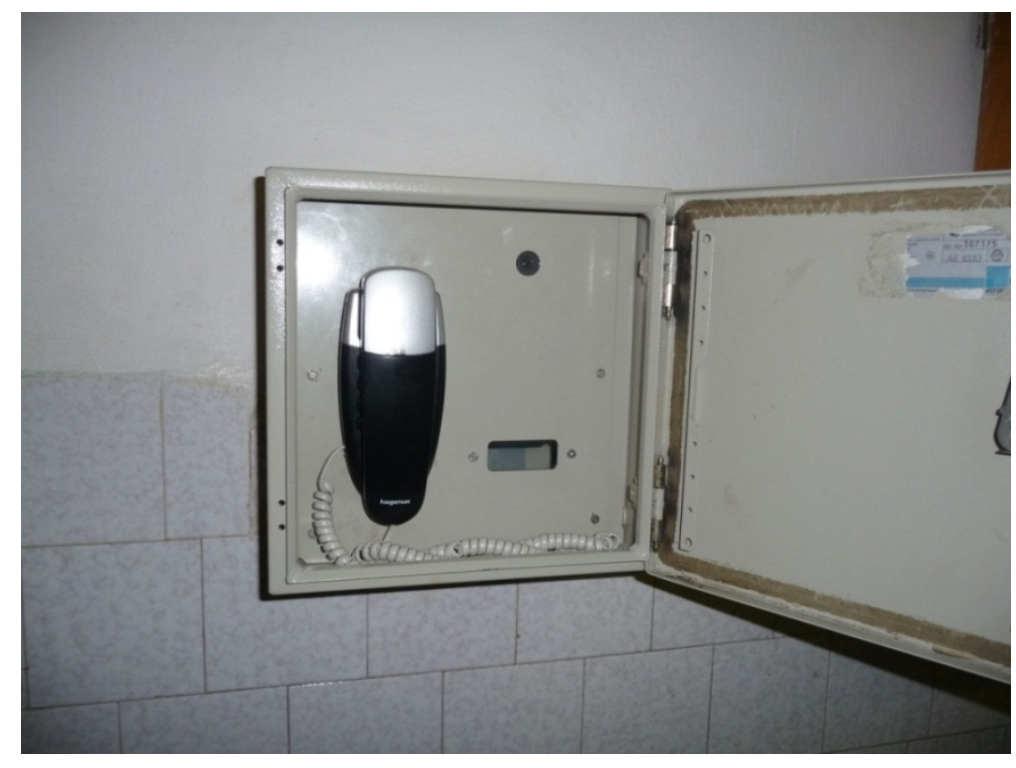

Figure no. 1: Prisoners' phone with the installed camera

(Source: Author, 2012) visible:

During the call, the following data are

- Prior to the identification of the inmate:

- the portrait photo taken by the camera;

- the state of the device.

- After the identification of the inmate:

- their personal data appear (name, cell number, penalty level, etc.);

- photo of the inmate (upon admission).

- After the inmate has made a phone call to a permitted number:

- the data of the dialled contact person (phone number, name, address, degree of family relationship);

- remaining time in confinement (Kondás, 2013).

\subsection{Shopping}

The phone system and the shopping account system is one and the same. In other words, purchases immediately show in the virtual account of the convict.
Naturally, the prison shop needs to comply with the regulations of the National Tax and Customs Administration. Nevertheless, as no cash is used, the price of the various purchased articles must be deducted from their balance. This process is aided by the barcode card. The goals of introducing a shopping system using a money register were the following:

The shop assistant can work with this money register licensed by the National Tax and Customs Administration in a manner they were used with the usual money registers.

Financial flows should occur online.

The convict can choose to spend their money on making calls or shopping.

Inmates can identify themselves with the same barcode card while making calls and while shopping. The system will deduct the used amount from the virtual bank account associated with the barcode card in both cases.

In order to prevent frauds, the computer next to the money register (see Figure no. 2) is to display the photo of the card owner upon each purchase. 


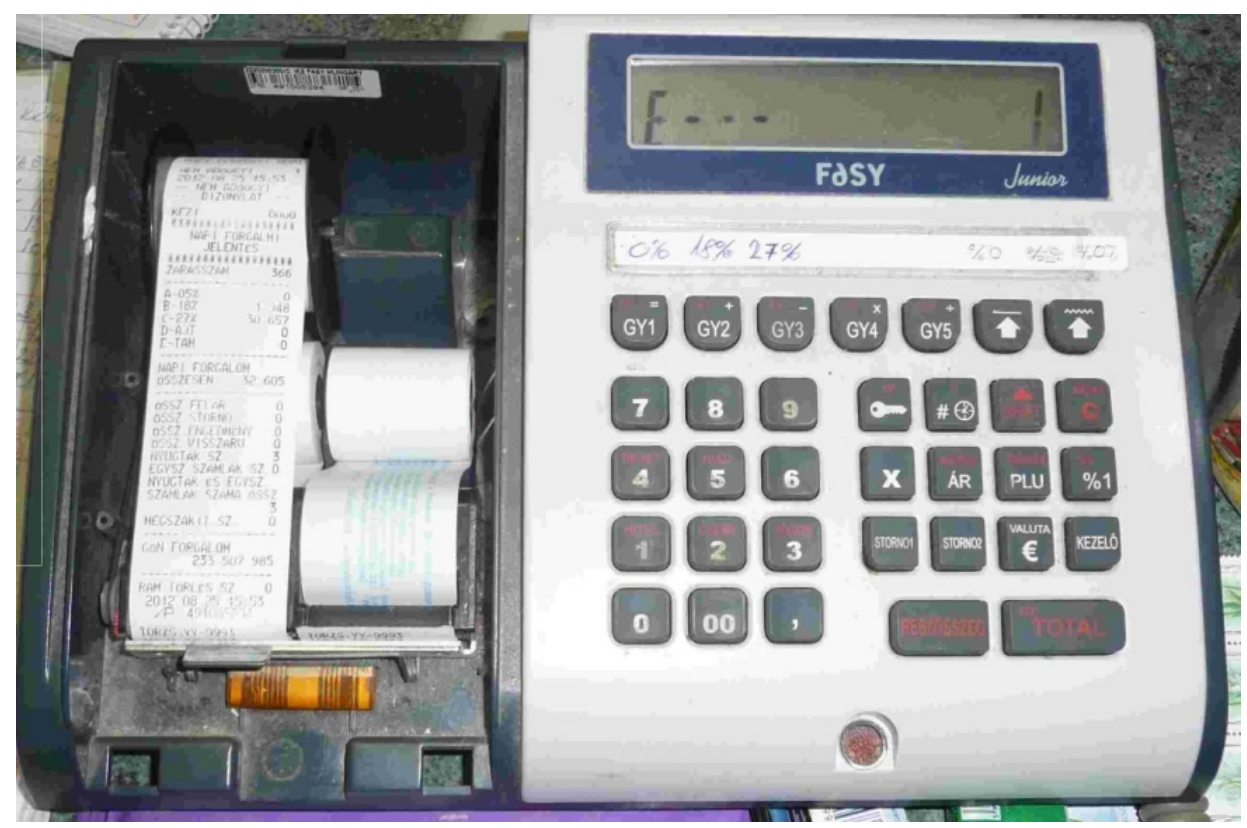

Figure no 2: Money register in use

(Source: Author, 2012)

With the help of the shop computer, the purchase procedure is the following:

- The convict hands over their barcode card to the shop assistant who reads the barcode information with the barcode reader. The monitor placed on the counter will display the card holder's photo and the personal data that were permitted by the given penal institution. For privacy reasons, only a moderate amount of data is entered in the system. Also, the shop assistant can view the overall sum available for use. The screen is visible for both the customer and the shop assistant, so the convict can easily decide how much money they wish to spend in the shop, on making calls or on shopping later.

- At the outset of the purchase, the inmate's register number (the unique identity number) is printed on the paper roll of the money register. When the purchase is completed, the system deducts the spent amount from the convict's virtual account and lists the purchase among their financial activities. The inmate signs the receipt (which contains their register number), and with this signature, they acknowledge the completion of the purchase (Kondás, 2013).

\section{Effectiveness of Identification} Methods

The identification system currently in use is effective. In the above chapters, I summed up the Penalty Enforcement Organisation data management based on the identification of convicts. For the use of the various systems, the application of the barcode card is essential. Without it, convicts cannot contact their family members; neither can they do shopping in the prison shop.

When an inmate enters the prison, their data are recorded, and they are photographed by the registration department. Thus, the information is available to release the barcode card, which stays with the convict as long as they are in confinement.

The barcode card is basically a means of payment. If it is photocopied or perhaps forged, then it will have duplicates. The card may, on occasion, get stolen, and its new "owner" might attempt to use it too. However, in practice, copying has little chance, even though we can never know when it occurs. It is more frequent that convicts lose their cards, and a new card must be released. The barcode of the new card will be identical to that on the lost card. 
Consequently, if the old card is retrieved, there will be two identical cards registered in the system. Therefore, it is necessary that greater attention is paid to the registration of barcode cards to prevent duplication.

Personal identification can be made even more secure by introducing more advanced technology. To identify convicts, a biometric identification system should be introduced in prisons so that convicts would not need to carry any identification items with them. As a result, the theft or loss of barcode cards would not represent a problem.

\section{Conclusions}

The barcode card-based identification of convicts was introduced nation-wide in Hungarian penal institutions in 2004. The system works logically, meets the requirements, and consequently, the financial transactions of inmates can be managed in a practical and easy way. The execution time of shopping and phone call has also been reduced.

The identification of convicts, however, would deserve to use new technologies keeping pace with the technological advances of the world. An identification system based on unique physical features $-\mathrm{a}$ biometric identification system - would be most suitable.

Should the present system of objectbased identification remain in force for a more extended period of time, a more robust and sturdy item, an RFID card, should be applied instead of the currently used barcode cards. The new card could also have a hologram and the card owner's photo on it. There is a wide range of options available; the application of our dream technology is only limited by the budget available to us.

The possibilities and defects of the current identification system help us set up our requirements regarding the future identification method.

An overall restructuring process of the Hungarian penalty enforcement system began in 2010, making use of European Union funds. The restructuring affected the modernisation of the networks, the increase in the number of termination points, the entirety of the IT system (servers, workstations) and the replacement of the registration system that used to be based on an obsolete software-technology. The purpose of this restructuring process was to set up a homogenous, standardised, firm and - on a national level - closed IT system, which thanks to a homogenous office environment - will ensure an identical infrastructural background for the operation of newly developed databases on each site of the organisation. Simultaneously, former IT systems have been replaced by new ones (Magyar, 2012).

The operation of penality enforcement was given a new legal basis in 2013 . Act CCXL of 2013 on the Enforcement of Penalties, Measures, Certain Coercive Measures and Detention for Misdemeanours also refers to the identification of convicts: "The penal institution operating within the framework of the Penalty Enforcement Organisation is obliged to check the personal identity of convicts. During this process, the personal identification data specified in the documents on which the prison admission is based are transferred to the criminal database and the photo-based of the penal institution; the authenticity of the data is re-checked" (Évi CCXL. Törvény, 2013). The penal institution also takes the convict's fingerprint and initiates the comparison with the criminal registration organ, in compliance with Part (5) b) of Section 82 of Act XLVII of 2009 on Criminal Conviction Records of Hungarian Citizens in any EU country and also on Criminal and Law Enforcement Biometric Data Records.

This comparison is conducted electronically by reading the fingerprint with a dedicated electronic device (Évi XLVII. Törvény, 2009). 
Thanks to the legal changes, convicts have the possibility to keep in touch with their family via mobile phones provided by the organisation. These are simplified cell phones whose use does not require selfidentification. Phones attached to the wall are taken out of service. Shopping in the prison shop is still card-based but modernised with a new IT system.

It is, therefore, still a relevant goal in Hungarian penal institutions to use an identification based on a more modern technology, where there is already an updated IT-background to support it.

\section{Acknowledgements}

This article was supported by Óbuda University.

\section{REFERENCES}

Évi XLVII. Törvény. (2009). Törvény a bünügyi nyilvántartási rendszerről, az Európai Unió tagállamainak bíróságai által magyar állampolgárokkal szemben hozott itéletek nyilvántartásáról, valamint a bünügyi és rendészeti biometrikus adatok nyilvántartásáról, available at: https://net.jogtar.hu/jogszabaly?docid=a0900047.tv, accessed on 05 January 2021.

Évi CCXL. Törvény. (2013). Törvény a büntetések, az intézkedések, egyes kényszerintézkedések és a szabálysértési elzárás végrehajtásáról, available at: https://net.jogtar.hu/jogszabaly?docid=a1300240.tv, accessed on 10 January 2021.

Hungarian Prison Service in Service of Justice. (2020). Available at: https://bv.gov.hu/hu/befogadasi-eljaras, accessed on 15 December 2020.

Kondás, K. (2013). Fogvatartotti azonosítás a büntetés-végrehajtásban. Diplomamunka, $13-40$.

Kondás, K. (2018). Adatok védelme a börtönökben. Hadmérnök, Vol. XIII, Issue 1, 269-277, available at: http://hadmernok.hu/181 21 kondas.pdf, accessed on 08 January 2021.

Kondás, K., \& Szücs, E. (2020). Special rules on personal identification in prison. Safety and Security Sciences Review, Vol. 2, No. 2, 15-21, available at: https://biztonsagtudomanyi.szemle.uni-obuda.hu/index.php/home/article/view/64/59, accessed on 13 December 2020.

Magyar, K. (2012). Magyar Közlöny 90. szám, 1236/2012. (VII. 12.) Korm. határozat Az Elektronikus Közigazgatás Operatív Program 2011-2013. évi akciótervének elfogadásáról, valamint kiemelt projektek nevesítéséről az Elektronikus Közigazgatás Operatív Program 2011- 2013.évi akciótervében és az Államreform Operatív Program 20112013. évi akciótervében, 2012 július 12), available at: https://magyarkozlony.hu/ dokumentumok/18148aa0c2ceff79db386b015f0b7a8e06036041/letoltes, accessed on 08 January 2021. 